\title{
The Effectiveness of Chitosan on Children's Dental and Oral Health as a Primary Preventive: A Literature Review
}

\author{
Ika Devi Adiana ${ }^{1}$ \\ ${ }^{1}$ Department of Pediatric Dentistry, Faculty of Dentistry, Universitas Sumatera Utara, Medan, Indonesia \\ ${ }^{*}$ Corresponding author. Email: devi_ika27@ rocketmail.com
}

\begin{abstract}
Children are the next generation of the nation who must be taken care of in every way, especially in their health. It is necessary to take care of children's overall health, including their dental and oral health. Maintaining oral and dental health is one of the good habits that should be taught from childhood. It will affect the child's overall health and have a worse impact if this is not taken care of earlier. However, the literature shows that chitosan is a natural material that is widely used in the medical field today, one of which is by adding chitosan as an ingredient to maintain the health of children's teeth and oral cavity. This article will review the related literature on the effectiveness of using chitosan as a natural ingredient in children's oral and dental health in primary prevention.
\end{abstract}

Keywords: Chitosan, Dental and oral Health, Primary Preventive, Children

\section{INTRODUCTION}

Dental and oral health problems, especially teeth with caries, are still a lot of complaints by children and adults. ${ }^{1}$ Based on The Global Burden of Disease Study 2016, dental and oral health problems, especially dental caries, are a disease that affects almost half of the world's population (3.58 billion people). Gum disease (periodontal) is the 11th most common disease in the world. While in the Asia Pacific, oral cancer is the 3rd most common type of cancer. Based on RISKESDAS 2018, North Sumatra Province has a lot of dental and oral health problems reaching $43.1 \%$ where the highest percentage is in children aged 5-9 years, which is 54\%. ${ }^{2}$ According to WHO the highest group is in children of 5 years old. ${ }^{3}$

If Dental caries is not treated immediately can make a negative impact on the mouth, affect the quality of life and systemic health such as experiencing pain, discomfort, infection, eating, and sleeping disorders. ${ }^{1}$ If this condition is untreated, it will affect the growth and development, appearance, speech, and self-confidence of the child. ${ }^{1,4,5}$ So that prevention and early treatment are very important, especially in children with high caries risk. $^{4}$
Caries prevention for each person is different based on the severity of the caries risk. In children with a history of moderate to high caries risk, treatment is needed as soon as possible and with the addition of remineralizing factors and antibacterial therapy for the prevention and patient care in children. ${ }^{6}$

Chitosan, a natural material derived from the exoskeleton of marine invertebrates such as shrimp and crabs, has a lot of benefits such as biocompatibility, biodegradable, and it also has anti-bacterial and antimicrobial properties, and mucoadhesive properties, so chitosan is often used in biomedical applications. From its properties, it can be concluded that chitosan can be used as an anti-bacterial, inhibit/kill microorganisms, reduce pain, improve physical properties and improve mechanical properties of materials in dentistry. ${ }^{7}$ The purpose of this literature review is to find the effectiveness of the use of chitosan as a natural ingredient in children's dental and oral health in primary prevention treatment. 


\section{LITERATURE REVIEW}

\subsection{Children's Oral and Dental Health}

According to the Regulation of the Minister of Health, number 89 in 2015 oral and dental health is the health condition of hard and soft tissues and elements in the oral cavity that allows individuals to eat, talk, and social interactions without dysfunction, aesthetic disturbances, and discomfort due to the presence of disease, occlusion deviation, and tooth loss so that they can live productive socially and economically. Dental and oral health is part of overall body health. ${ }^{2}$ To achieve Indonesia caries-free in 2030, whos is a WHO recommendation it would hope that newborns in 2018 at the age of 12 years will not experience caries. To achieve this, preventive measures and special care have been taken to reduce child risk and improve overall oral health. ${ }^{2}$

\subsection{Primary Prevention}

Primary prevention is a form of preventive procedure carried out before clinical symptoms of the disease arise. Primary prevention aims to prevent illness and maintain physiological balance. There are several ways of primary prevention in a child including modification of children's habits (oral hygiene and sugar diet), dental protection (use of silicone, fluorine, and chlorhexidine), and plaque control (brushing teeth, dental floss, and antibiotics) ${ }^{8}$

\subsection{Chitosan}

Chitosan is a natural material that is the result of $\mathrm{N}$ acetylated from chitin which is a natural biopolymer and consists of poly-(2-amino2-deoxy- $\beta$-(1-4)D_glucopyranose) with the molecular formula ( C6H11NO4) that can widely found in marine animals like crabs, shrimp, blanks, and crabs. In addition, chitosan can also be found in insects and fungi. The usefulness of chitosan as a versatile material cannot be separated from the natural nature of chitosan and has excellent chemical and biological properties because it can be used in industry and the health sector. Chitosan in biomedicine must have a degree of deacetylation between 75\% - 98\%.9,10,11 Currently, chitosan is being developed and researched with nanotechnology with sizes ranging from 10-1000 $\mathrm{nm}$. The application of chitosan can be increased by modifying it chemically or physically through the combination of chitosan with several other polymers, both natural and synthetic polymers. ${ }^{9,12}$

\subsection{Use of Chitosan}

Currently, chitosan is widely used in various fields including industry, medicine, and health, one of which is dentistry which continues to be developing in many studies. The uses of chitosan in dentistry include wound healing, antibacterial, anti-inflammatory, root canal dressings, hemostatic agents, and improving some properties of dental materials. ${ }^{13}$

As wound care, chitosan membrane is used and made porous to facilitate air circulation and prevent water accumulation in the wound so the wound will dry up and heal quickly. As an antibacterial agent, chitosan has wide-spectrum antimicrobials that can fight grampositive bacteria, gram-negative bacteria, and fungi, so chitosan has the potential to prevent caries. ${ }^{14}$ The use of chitosan as a root canal dressing material is very nice because chitosan has biocompatible, biodegradable properties and has an antibacterial effect. One study by Silva and colleagues stated that the use of $0.2 \%$ chitosan as root canal irrigation material was very effective in removing the smear layer from the middle and apical $1 / 3$ of the root canal..$^{15}$ In addition, chitosan can also improve some of the properties of dental materials by modifying it by adding chitosan to other chemicals, according to research by Lee and colleagues in 2012 who stated that the mechanical properties of composite membranes increased with increasing concentrations of chitosan. ${ }^{16}$

\section{EFFECTIVENESS OF CHITOSAN IN PRIMARY PREVENTION}

Early childhood caries (ECC) is one of the most common caries in children. One of the causes is Streptococcus mutans bacteria. Caries prevention can be an application by applying a proper diet. Selection of the right diet can suppress the growth of Streptococcus mutans. Chitosan is a natural biopolymer as antibacterial and can be combined with food or beverage ingredients including Chewable lozenges. According to research conducted by Ahmad and his friends in 2020, children who chewed $2 \%$ chitosan Chewable lozenges showed the effectiveness of reducing the number of Streptococcus mutans colonies significantly in cases of early childhood caries in children. ${ }^{17}$

Khazaei and Adabi stated that school children who chewed chitosan-containing gum for 5 minutes showed a positive effect in reducing the number of mutants streptococcal colonies in saliva compared to the control group but had no significant effect on increasing the $\mathrm{pH}$ of saliva. ${ }^{18}$

\subsection{Chitosan as Dental Protection}

Dental caries is one of the major public health problems and a general disease among the global 
population. The use of fluoride is one of the most effective ways to prevent tooth decay, clinically, dental caries has been characterized by demineralization of teeth where demineralization occurs due to an imbalance between the dissolution of calcium phosphate from the mineral enamel and the remineralization process. Although dental caries could be prevented, they can also fail due to many factors. Ebrahimi and colleagues stated that the synthesized fluoride/chitosan nanoparticles were a promising way to provide fluoride for the early prevention of tooth decay. ${ }^{19}$ Simeonov and colleagues in their research developed a chitosan microgel hybrid which showed an effective agent for enhancing remineralization of early caries development and carried out an early-stage approach that has been tested and proved effective for early demineralization of enamel remineralization. ${ }^{20}$

In elementary school children, the level of oral hygiene is low, so it can increase the incidence of dental and oral diseases caused by various microorganisms. To maintain the cleanliness of the teeth and oral cavity, mouthwash is needed. However, mouthwash on the market contains a lot of alcohol, causing side effects that are not good for children. Therefore, the use of chitosan mouthwash is the best alternative as a natural ingredient that is biocompatible and safe for children because it is not toxic. In some cases, using mouthwash is very important because it can remove bacteria that cannot occur with teeth. ${ }^{21}$

Research conducted by Komariah and colleagues showed that the formulation of chitosan with mouthwash containing calcium could reduce the number of oral bacterial colonies in elementary school children. The use of a higher concentration of mouthwash formulations reduce the number of bacterial colonies in the mouth. ${ }^{22}$

\subsection{Chitosan as Plaque Control}

Caries at an early age are one of the most common dental caries. One of the causes is Streptococcus mutans bacteria. The most effective method of preventing plaque accumulation is brushing your teeth with toothpaste. Chitosan is a natural biopolymer as an antibacterial and can be combined with toothpaste. According to research conducted by Achmad and friends in 2017 , caries cases in early childhood using $5 \%$ chitosan toothpaste was effective in reducing the number of streptococcal mutans bacteria colonies. ${ }^{23}$ Syang's research conducted by Ozalp and Tulunoglu stated that the abrasive effect of toothpaste containing chitosan had a lower abrasion value than toothpaste containing propolis on healthy and demineralized primary tooth enamel. ${ }^{24}$ Meanwhile, according to research by Pini and friends, it was stated that the viscosity of chitosan affected the efficacy of $\mathrm{F} / \mathrm{Sn}$ toothpaste. Under erosive/abrasive conditions. Chitosan 1000 showed the best protective effect with higher tin retention than chitosan biopolymer showed a protective effect against erosion and enamel erosion. ${ }^{25}$

\section{AUTHORS' CONTRIBUTIONS}

Essie Octiara and Ami Angela gave approval for the final submitted version.

\section{ACKNOWLEDGMENTS}

The authors would like to thanks academic staff of Pediatric Dentistry Department, Faculty of Dentistry, Universitas Sumatera Utara for the support.

\section{REFERENCES}

[1] Abdullah N. Hubungan status kesehatan gigi dan mulut anak sekolah dengan pelaksanaan UKGs di sekolah dasarr dan sederajat se kota Makasar. Media kesehatan gigi politeknik kesehatan gigi masyarakat. 2018; Vol 17, No 1.

[2] Kementerian kesehatan Indonesia. 2019.pusdatin.kemenkes.go.id hal 2

[3] Balitbang Kemenkes RI. 2018. Riset Kesehatan Dasar; RISKESDAS. Jakarta: Balitbang Kemenkes RI.hal 182-196.

[4] The Challenge of Oral Disease - A call for global action. The Oral H. Geneva: FDI World Dental Federation; 2015.

[5] Hummel J, Phillips K, Holt B, Hayes C. Oral Health: An Essential Component of Primary Care. Qualis Heal. 2015;(June):1-67.

[6] AAPD. Guideline on Caries-risk Assessment and Management for Infants , Children , and Adolescents. Clin Pract Guidel. 2014;38(6):142150.

[7] Hasri Prospek Kitosan dan Kitosan Termodifikasi Sebagai Biopolimer Alami yang Menjanjikan. J Chem. 2010;11(2):1-10.

[8] RamayantiS S, Purnakarya I. Peran makanan terhadap kejadian karies gigi. Jumal Kesehatan Masyarakat, Maret 2013 - September 2013, Vol. 7, No.2.

[9] Sugita P, Wukisari T, Sjahriza A, Wahyono A. kitosan sumner biomaterial masa depan.Bogor: IPB PRESS 2009;20-30.

[10] Diab MA, El- Sonbati AZ, Al-Halawany MM, Barder DMD. Thermal Stability and Degradation 
of chitosan modified by cinnamic acid. Open Journal of Polymer Chemistry. 2012; 2;14-20.

[11] Ahmed S, Ikram S. Chitosan: Derivatives, Composites and Applications [Internet]. Beverly: Scrivener Publishing; 2017.503 p. Available from: http://doi.wiley.com/10.1002/9781119364849

[12] Chandrasekaran M, Kim KD, Chun SC. Antibacterial activity of chitosan nanoparticles: A review. Processes. 2020;8(9):1-21.

[13] Matica MA, Aachmann FL, Tøndervik A, Sletta H, Ostafe V. Chitosan as a wound dressing starting material: Antimicrobial properties and mode of action. Int J Mol Sci. 2019;20(23):1-33.

[14] Kong M, Chen XG, Xing K, Park HJ. Antimicrobial properties of chitosan and mode of action: A state of the art review. Int $\mathbf{J}$ Food Microbiol [Internet]. 2010;144(1):51-63. Available from:

http://dx.doi.org/10.1016/j.ijfoodmicro.2010.09.01 $\underline{2}$

[15] Silva PV, Guedes DF, Nakadi FV, Pecora JD, Cruz-PilhoAm. Chitosan : a new solution for removable of smear layer after root canal instrumentation. Int Endod J 2013;46(4);332-8.

[16] Lee SB, Kwon JS, Lee YK, Kim KM, Kin KN. Bioactivity and mechanical properties of collagen composite membranes reinforcedby chitosan and $\beta$ tricalcium phosphate. J Biomedical Materials Res b Appl Biomaterial;2012; 100 B (7) ;1935-1942.

[17] Achmad H, Tanumihardja M, Sartini, Ramadhany S, Marhamah, Singgih F, Ramadhany YF, Mutmainnah N. Chewable Lozenges using White Shrimp Waste (Litopenaeus vannamei) in Reduce Colonization of Bacteria Streptococcus mutans in the Case of Early Childhood Caries Sys Rev Pharm Journal 2020; 11(4): 293299.

[18] Khamverdi Z, Farhadian F, Khazaei S , Adabi M. Efficacy of chitosan-based chewing gum on reducing salivary $\mathrm{S}$. mutans counts and salivary pH: a randomised clinical trial. Acta Odontologica Scandinavica 2021; 79(4):268-274.

[19] Ebrahimi N, Rashidiani J, Soleimani AA, Malekafzali B. Chitosan/Fluoride Nanoparticles for Preventing Dental Caries.2019. DOI:10.2174/2542579X01666190212150457

[20] Simeonov M, Gussiysk A, Mironova J, Nikolova D, Apostolov A, Sezanova K, Dyulgerova E, Vassileva E. Novel hybrid chitosan/calcium phosphates microgels for remineralization of demineralized enamel - A model study European Polymer Journal119 (2019) 14-2.
[21] Schaeffer LM, Szewczyk, G, Nesta J, Mark V, DuThumm L, Williams I, Arvanitidou E. In vitro antibacterial efficacy of cetylpyridinium chloridecontaining mouthwashes. Clin. Den. 2011: 22: 183-18.

[22] Komariah A, Tatara RA, Bustam DA, Efficacy of Rhinoceros Beetle (Xylotrupes Gideon) Nano Chitosan and Calcium Mouthwash in Reducing Quantity Oral Cavity Bacteria among Elementary School Age Children. International Journal of Advanced Biological and Biomedical Research. 2017: 5(1); 41-47.

[23] Achmad H, Ramadhany YF. Effectiveness of Chitosan Tooth Paste from White Shrimp (Litopenaeusvannamei) to Reduce Number of Streptococcus Mutans in the Case of Early Childhood Caries. Journal of International Dental and Medical Research.vol 10 no 2 thn 2017 hal 358 $-363$.

[24] Ozalp S, Tulunoglu O. SEM-EDX analysis of brushing abrasion of chitosan and propolis based toothpastes on sound and artificial carious primary enamel surfaces. International Journal of Paediatric Dentistry.2014; 24 (5) : 349-357.

[25] Pini NIP, Lima DAN, Luka B, Ganss C, Schlueter $\mathrm{N}$. Viscosity of chitosan impacts the efficacy of $\mathrm{F} / \mathrm{Sn}$ containing tooth pastes against erosive/abrasive wear in enamel. 2020; Journal of Dentistry(92).1-7. 